\title{
HUBUNGAN PENGETAHUAN IBU DENGAN PEMBERIAN ASI EKSKLUSIF DI PUSKESMAS PERDAGANGAN KABUPATEN SIMALUNGUN
}

\author{
Derma Wani Damanik \\ Akper Kesdam I/Bukit Barisan Pematangsiantar \\ Email:dermawanidamanik@gmail.com
}

\begin{abstract}
Exclusive breastfeeding is breast milk that given to babies from birth for six months without and / or replace with other food or drinks. Exclusive breastfeeding can provide the immunity needed for the growth and development of infants. The purpose of this study was to examine the relationship between knowledge and exclusive breastfeeding at Perdagangan Health Center in Simalungun Regency. The population is in this study were all mothers who have infants aged 7-12 months who live at Perdagangan Health Center in Simalungun Regency. The sample in this study was 115 respondents. The study was conducted from September 2 to October 1, 2019. The instrument in this study used a questionnaire created by the researcher. Statistical test is using Chi-square. The results of the study obtained at Perdagangan Health Center in Simalungun Regency that the majority of mothers' knowledge about exclusive breastfeeding is in the poor category of 78 respondents (67.8\%), the majority of mothers do not provide exclusive breastfeeding, namely 92 respondents (80\%). Statistical test results show that $P$-value is $0.01<0.05$, so that the null hypothesis $(\mathrm{HO})$ is rejected, which means there is a significant relationship between maternal knowledge and exclusive breastfeeding. It is recommended that health workers who work in the area of the mother and child area should improve education programs for pregnant and breastfeeding mothers to increase the knowledge and interest of mothers to breastfeed exclusively in the first six months of a baby's life.
\end{abstract}

\section{Keywords: knowledge, mother, exclusive breastfeeding}

\section{PENDAHULUAN}

ASI Eksklusif merupakan ASI yang diberikan kepada bayi sejak dilahirkan selama enam bulan tanpa dan/atau mengganti dengan makanan atau minuman lain (Peraturan Pemerintah RI No.33 Tahun, 2012 ; Safdar, 2017). Air Susu Ibu (ASI) secara eksklusif dapat memberikan kekebalan yang diperlukan untuk pertumbuhan dan perkembangan bayi pada bulan-bulan pertama (Elad et al., 2014). ASI juga dianggap sebagai vaksin pertama untuk bayi, yang mengandung antibodi untuk memberikan perlindungan imunologis terhadap kematian akibat penyakit menular (Al-Abedi \& Al-Asadi, 2016).

Menurut pendapat Maharlouei, Pourhaghighi, Raeisi, Zohoori, dan Lankarani (2018), ASI Eksklusif dapat mengurangi morbiditas dan total kematian bayi di tahun pertama kehidupan, termasuk penyakit diare, infeksi, dan reaksi alergi.

Organisasi Kesehatan Dunia (WHO) merekomendasikan pemberian ASI eksklusif selama 6 bulan pertama kehidupan, diikuti oleh lanjutan 
menyusui dengan makanan pendamping yang sesuai hingga 2 tahun atau lebih (World Health Organisation [WHO], 2017) karena pemberian ASI secara eksklusif sampai 6 bulan dan dilanjutkan hingga 2 tahun dapat menurunkan angka kesakitan dan kematian bayi, mengurangi risiko penyakit kronis, dan membantu perkembangan bayi (Kemenkes RI, 2015).

Menyusui adalah cara normal dalam memberikan bayi nutrisi yang dibutuhkan bagi perkembangan yang tepat (Orabi, al-Sayad, \& Alharthi, 2017); (Nandini, Handayani, Chalidyanto, Pudjirahardjo, \& Putri, 2019) mengungkapkan bahwa menyusui bukan hanya tindakan menyusui bayi, tetapi dalam proses itu ada ikatan psikologis dari ibu dan bayi. Menyusui sebagai landasan bagi kelangsungan hidup anak, nutrisi dan perkembangan serta kesehatan ibu (WHO, 2017). Menyusui secara eksklusif merupakan nutrisi terbaik dan terlengkap untuk bayi selama enam bulan pertama kehidupan bagi pertumbuhan dan perkembangan yang sehat (Srimiyati, 2018; Splendor, et al, 2019). Menyusui sangat penting bagi ibu (Huang, Ren, Liu, Luo, \& Zhao, 2017) dan bayi untuk tumbuh secara sehat (Keloglan, Yilmaz, dan Gumus, 2018).

Secara global, tingkat menyusui jauh lebih rendah dari yang dibutuhkan untuk perlindungan yang optimal bagi kesehatan ibu dan anak. Kurang dari setengah bayi yang baru lahir mulai menyusui pada satu jam pertama setelah lahir (WHO, 2015), dan kurang dari $41 \%$ bayi berusia kurang dari 6 bulan secara eksklusif disusui (Maryam, Moniralsadat, Zohreh, Banafsheh, dan Amir, 2014). Hal tersebut jauh dari target global tahun 2030 yaitu besar cakupan sebanyak 70\% (WHO, 2015).

Menyusui secara eksklusif merupakan target global, namun dalam pelaksanaannya pemberian ASI eksklusif oleh ibu, masih mengalami banyak hambatan dan kendala (Susilowati, Suryawan, \& Widiasa, 2018). Nukpezah, Nuvor, dan Ninnoni (2018) mengungkapkan bahwa prevalensi pemberian ASI eksklusif (EBF) selama enam bulan pertama kehidupan tetap rendah di seluruh dunia. Safdar (2017) menambahkan prevalensi menyusui eksklusif di Negara Pakistan bahkan hanya mencapai $38 \%$.

Sejalan dengan hasil penelitian Cascone, Tomassoni, Napolitano, dan Giuseppe (2019) di Itali diperoleh bahwa hanya hanya $33,3 \%$ ibu memberikan ASI Eksklusif selama enam bulan pertama. Proporsi pola pemberian ASI Eksklusif pada bayi umur 0-5 bulan di Indonesia juga hanya mencapai 37,3\% (Kemenkes RI, 2018). Oleh karena itu, pengetahuan tentang 
menyusui di kalangan ibu atau wanita menjadi hal penting untuk menjadikan anak-anak yang sehat (Afrose, Banu, Ahmed, \& Khanom, 2012). Pengetahuan merupakan salah satu faktor pendukung untuk perubahan perilaku, termasuk dalam tindakan memberikan ASI secara eksklusif (Susilowati et al., 2018).

\section{METODE}

Penelitian ini merupakan penelitian kuantitatif dengan menggunakan desain deskriptif korelasi dengan pendekatan pengamatan sewaktu (cross sectional).

Tujuan penelitian ini untuk menguji hubungan antara pengetahuan dengan pemberian ASI Eksklusif di wilayah kerja Puskesmas Perdagangan Kabupaten Simalungun. Sampel penelitian menggunakan total populasi. Populasi dalam penelitian adalah seluruh ibu yang mempunyai bayi usia 7-12 bulan yang tinggal di wilayah kerja Puskesmas Perdagangan Kabupaten Simalungun yaitu sebanyak 115 responden. Penelitian telah dilakukan sejak tanggal 2 September sampai dengan 1 Oktober 2019.

Instrumen pada penelitian ini menggunakan kuesioner yang dibuat sendiri oleh peneliti yang terdiri dari 5 pertanyaan tentang pemberian ASI Eksklusif dan 20 pernyataan tentang pengetahuan. Uji statistik menggunakan Chi-square.
HASIL DAN PEMBAHASAN

Hasil Penelitian

Tabel 1. Distribusi Frekuensi Data Demografi Responden

\begin{tabular}{clrr}
\hline No & $\begin{array}{c}\text { Identitas } \\
\text { Responden }\end{array}$ & \multicolumn{1}{c}{$\boldsymbol{f}$} & \multicolumn{1}{c}{$\%$} \\
\hline 1. & Umur (tahun) & & \\
& $<25$ tahun & 18 & 15,7 \\
& 25-35 tahun & 93 & 80,9 \\
& $>35$ tahun & 4 & 3,4 \\
\hline 2. & Pendidikan & & \\
& SD & 20 & 17,4 \\
& SLTP & 26 & 22,6 \\
& SMA & 54 & 47 \\
& Perguruan Tinggi & 15 & 13 \\
\hline 3. & Pekerjaan Ibu & & \\
& Bekerja & 18 & 16 \\
& Tidak Bekerja & 97 & 84 \\
\hline 4. & Pendapatan & & \\
& Keluarga & 75 & 62,2 \\
& $<2.500 .000$ & 40 & 37,8 \\
& $>2.500 .000$ & & \\
\hline & Jumlah & 115 & 100 \\
\hline
\end{tabular}

Berdasarkan tabel 1 dapat diketahui bahwa umur responden mayoritas berada pada rentang 25-35 yaitu sebanyak 93 responden $(80,9 \%)$, tingkat pendidikan mayoritas SMA sebanyak 54 responden (47\%), sebagian besar tidak bekerja sebanyak 97 responden (84\%), mayoritas pendapatan keluarga $<2.500 .000$ sebanyak 75 responden $(62,2 \%)$.

\section{Tabel 2. Distribusi Frekuensi Pengetahuan Ibu tentang ASI Eksklusif}

\begin{tabular}{ccrr}
\hline No & Pengetahuan & \multicolumn{1}{c}{$\boldsymbol{f}$} & \multicolumn{1}{c}{} \\
\hline 1. & Baik & 37 & 32,2 \\
2. & Kurang Baik & 78 & 67,8 \\
\hline & Jumlah & 115 & 100 \\
\hline
\end{tabular}


Tabel 2 menunjukkan bahwa mayoritas pengetahuan Ibu tentang Pemberian ASI Eksklusif berada pada kategori kurang baik yaitu sebanyak 78 responden $(67,8 \%)$.

Tabel 3. Distribusi Frekuensi Pemberian ASI Eksklusif

\begin{tabular}{ccrr}
\hline No & $\begin{array}{c}\text { Pemberian ASI } \\
\text { Eksklusif }\end{array}$ & \multicolumn{1}{c}{$\boldsymbol{f}$} & \multicolumn{1}{c}{$\boldsymbol{\%}$} \\
\hline 1. & Eksklusif & 23 & 20 \\
2. & Tidak Eksklusif & 92 & 80 \\
\hline & Jumlah & 115 & 100 \\
\hline
\end{tabular}

Berdasarkan tabel 3 diperoleh bahwa mayoritas ibu tidak memberikan ASI Eksklusif yaitu sebanyak 92 responden $(80 \%)$.

\section{Tabel 4. Distribusi Pengetahuan Pemberian ASI Eksklusif pada Bayi}

\begin{tabular}{lrrrrrr}
\hline \multirow{2}{*}{$\begin{array}{l}\text { Pengeta- } \\
\text { huan }\end{array}$} & \multicolumn{2}{c}{$\begin{array}{c}\text { Pemberian } \\
\text { ASI } \\
\text { Eksklusif }\end{array}$} & Total & $\begin{array}{c}\text { Nilai } \\
\text { a }\end{array}$ & $\begin{array}{c}\boldsymbol{P} \text { - } \\
\text { value }\end{array}$ & $\mathbf{X}$ \\
\cline { 2 - 3 } & Ya & Tidak & & & & \\
\hline Baik & 14 & 23 & 37 & & & \\
Kurang & 9 & 69 & 78 & 0.05 & 0.01 & 10 \\
Baik & & & & & & 4 \\
\hline \multicolumn{1}{c}{ Total } & 23 & 92 & 115 & & & \\
\hline
\end{tabular}

Berdasarkan tabel abel 4 menunjukkan bahwa dari 37 ibu yang berpengetahuan baik, sebanyak 14 responden diantaranya memberikan ASI Eksklusif dan 23 responden tidak memberikan ASI Eksklusif. Sedangkan dari 78 responden yang tingat pengetahuannya kurang baik, sebanyak 9 orang memberikan ASI Eksklusif dan 69 orang tidak memberikan ASI
Eksklusif. Hasil uji statistik menunjukkan bahwa p-value sebesar 0.01 , yang berarti nilai $p$-value $<0,05$ sehingga hipotesa nol (HO) ditolak sehingga diperoleh bahwa ada hubungan yang signifikan antara pengetahuan ibu dengan pemberian ASI Eksklusif di wilayah kerja Puskesmas Perdagangan Kabupaten Simalungun.

\section{Pembahasan}

\section{Pengetahuan Ibu tentang Pemberian ASI Eksklusif}

Hasil penelitian di wilayah kerja Puskesmas Perdagangan Kabupaten Simalungun menunjukkan bahwa pengetahuan ibu mayoritas berada pada kategori kurang baik yaitu sebanyak 78 responden (67,8\%). Asumsi peneliti hal ini disebabkan karena tingkat pendidikan responden yang masih 'rendah dimana sebagian besar masih merupakan lulusan SMA. (Al-Abedi \& Al-Asadi, 2016) menyatakan bahwa ${ }_{48}^{10}$ salah satu faktor yang mempengaruhi pengetahuan adalah tingkat pendidikan.

Pendapat Notoatmodjo (2012), tingkat pendidikan merupakan jenjang pendidikan yang dicapai paling akhir. Tingkat pendidikan merupakan suatu standar yang menunjukkan seseorang dapat berperilaku dengan cara yang ilmiah. Pendidikan memiliki peran utama dalam mempromosikan pemberian ASI (Bascom \& Napolitano, 2016). Seseorang dengan tingkat pendidikan rendah akan sulit memahami 
pesan atau informasi yang tersampaikan (Pitaloka, Abrory, dan Pramita, 2018).

Pengetahuan merupakan faktor penting untuk keberhasilan menyusui (Handayani, Mohd Kosnin, \& Kee Jiar, 2012) Sejalan dengan penelitian Mogre, Dery, dan Gaa (2016) bahwa pengetahuan tentang ASI eksklusif merupakan faktor penentu dalam praktik pemberian ASI Eksklusif. Memahami pengetahuan dan sikap ibu membantu dapat meningkatkan pemberian ASI eksklusif guna mengurangi angka kesakitan dan kematian bayi. Penelitian Al-Abedi dan Al-Asadi (2016) menambahkan bahwa pengetahuan yang baik tentang menyusui merekomendasi ibu untuk meningkatkan pengetahuan dan minat mereka menyusui eksklusif dalam enam bulan pertama kehidupan bayi. Sebaliknya pengetahuan yang salah dan rendah tentang pemberian ASI eksklusif akan mengakibatkan berkurangnya jumlah bayi yang mendapatkan ASI secara eksklusif (Bo, O \& Agwo, 2014).

\section{Pemberian ASI Eksklusif}

Hasil penelitian di wilayah kerja Puskesmas Perdagangan Kabupaten Simalungun menunjukkan bahwa mayoritas ibu tidak memberikan ASI Eksklusif yaitu sebanyak 92 responden (80\%). Asumsi peneliti hal tersebut disebabkan karena tingkat pengetahuan responden yang mayoritas masih berada pada kategori kurang baik. Susilowati, S.D, Suryawan, I.W.B dan Widiasa, A.A.M (2018) menyatakan bahwa terdapat banyak faktor yang berkontribusi dalam pemenuhan target pemberian ASI eksklusif. Pengetahuan menjadi dasar perubahan perilaku, termasuk perilaku ibu.

Penelitian Cascone et al. (2019) menyatakan bahwa responden percaya pemberian ASI Eksklusif sangat penting bagi kesehatan ibu dan anak, mayoritas responden percaya menyusui dapat memberikan nutrisi terbaik untuk bayi dalam enam bulan pertama kehidupan sebanyak 91,1\%, menyusui adalah nutrisi paling sederhana untuk ibu $61,9 \%$, menciptakan hubungan positif antara ibu dan anak 76,3\% dan membantu menurunkan berat badan selama kehamilan

Akinyinka (2016) menambahkan bahwa pemberian ASI Eksklusif unggul secara unik sebagai sumber nutrisi untuk bayi, dan ASI memiliki sangat banyak manfaat. Didukung oleh pendapat Ozenoglu, Kaya, Ulus, dan Alakus (2017) bahwa menyusui memberikan manfaat bagi kesejahteraan bayi dan ibu. Bayi yang disusui akan lebih tinggi skor kecerdasan daripada bayi yang tidak disusui. Sebaliknya jika nutrisi anak pada usia dini kurang/buruk dapat berdampak negatif pada perkembangan fisik dan emosional anak baik dalam 
jangka pendek dan jangka panjang, serta terbatasnya prestasi dan produktivitas orang ketika kelak dewasa (Cascone et al., 2019).

\section{Hubungan pengetahuan Ibu dengan pemberian ASI Eksklusif}

Hasil analisis dengan program SPSS diperoleh nilai statistik p-value $0.01<$ 0,05 , nilai $\chi^{\mathrm{a}} 10.848$ a sehingga hipotesa nol (HO) ditolak yang berarti ada hubungan yang signifikan antara pengetahuan ibu dengan pemberian ASI Eksklusif di wilayah kerja Puskesmas Perdagangan Simalungun.

Menurut Akinyinka (2016) bahwa ada hubungan yang baik antara pengetahuan ibu dengan pemberian ASI Eksklusif. Ibu yang memiliki pengetahuan yang baik akan memberikan ASI secara Eksklusif. Sesuai dengan penelitian Dallak, AlRabeei, dan Aljahmi (2016) kurangnya pengetahuan dan sikap sangat berpengaruh terhadap praktik menyusui. Penelitian Septiani, Budi, dan Karbito (2017) yang menyatakan faktor yang paling dominan berhubungan dengan pemberian ASI eksklusif adalah pengetahuan. Ibu dengan pengetahuan yang baik memiliki peluang untuk dapat memberikan ASI eksklusif sebesar 13 kali lebih besar dibandingkan ibu yang memiliki pengetahuan kurang.

Berbeda dengan penelitian Pitaloka et al. (2018) yang menyatakan bahwa tidak ada hubungan yang signifikan antara pengetahuan ibu, pendidikan dan praktik pemberian ASI eksklusif di kalangan ibu, namun ada faktor lain yang berpengaruh terhadap pemberian ASI Eksklusif diantaranya stres emosional, kurangnya dukungan dari masyarakat dan tenaga kesehatan profesional, produksi ASI yang rendah, sakit atau pembengkakan pada putting susu (Diji et al., 2017).

\section{KESIMPULAN DAN SARAN}

\section{Kesimpulan}

1. Mayoritas pengetahuan Ibu tentang Pemberian ASI Eksklusif kurang baik yaitu sebanyak 78 responden $(67,8 \%)$.

2. Mayoritas ibu tidak memberikan ASI Eksklusif yaitu sebanyak 92 responden $(80 \%)$.

3. Ada hubungan yang signifikan antara pengetahuan ibu dengan pemberian ASI Eksklusif di wilayah kerja Puskesmas Perdagangan Kabupaten Simalungun.

\section{Saran}

Disarankan kepada tenaga kesehatan yang bertugas pada bidang area ibu dan anak hendaknya meningkatkan program pendidikan untuk ibu hamil dan menyusui guna meningkatkan pengetahuan dan minat ibu untuk menyusui secara Eksklusif dalam enam bulan pertama kehidupan bayi. 


\section{DAFTAR PUSTAKA}

Afrose, L., Banu, B., Ahmed, K., \& Khanom, K. (2012). Factors associated with knowledge about breastfeeding among female garment workers in Dhaka city. WHO SouthEast Asia Journal of Public Health. https://doi.org/10.4103/22243151.207021

Akinyinka, M. (2016). Breastfeeding Knowledge and practices among mothers of children under 2 years of age living in a Military Barrack in Southwest Nigeria. International Journal of MCH and AIDS (IJMA). https://doi.org/10.21106/ijma.79

Al-Abedi, N .F. H., \& Al-Asadi, K. M. N. (2016). Assessment of mother's knowledge toward breastfeeding at AL-Najaf City. International Journal of Scientific and Research Publications, 6(12), 31-38. Retrieved from http://www.ijsrp.org/researchpaper-1216/ijsrp-p6007.pdf

Bascom, E. M. E., \& Napolitano, M. A. (2016). Breastfeeding duration and primary reasons for breastfeeding cessation among women with postpartum depressive symptoms. Journal of Human Lactation. https://doi.org/10.1177/08903344156 19908

Cascone, D., Tomassoni, D., Napolitano, F., \& Di Giuseppe, G. (2019). Evaluation of knowledge, attitudes, and practices about exclusive breastfeeding among women in Italy. International Journal of Environmental Research and Public Health. https://doi.org/10.3390/ijerph161221 18

Dallak, A.M, Al-Rabeei, N.A, \& Aljahmi, Y. A. (2016). Breastfeeding knowledge, attitude, and practices among Mothers Attending Health Centers in Sana'a City. ARC Journal of Public Health and Community Medicine.

https://doi.org/10.20431/24560596.0102003

Diji, A. K. A., Bam, V., Asante, E.,
Lomotey, A. Y., Yeboah, S., \& Owusu, H. A. (2017). Challenges and predictors of exclusive breastfeeding among mothers attending the child welfare clinic at a regional hospital in Ghana: A descriptive cross-sectional study. International Breastfeeding Journal. https://doi.org/10.1186/s1 3006-017-0104-2

Elad, D., Kozlovsky, P., Blum, O., Laine, A. F., Jack Po, M., Botzer, E., ... Sirae, L. Ben. (2014). Biomechanics of milk extraction during breast-feeding. Proceedings of the National Academy of Sciences of the United States of America. https://doi.org/10.1073/pnas.1319798 111

Handayani, L., Mohd Kosnin, A., \& Kee Jiar, Y. (2012). Breastfeeding education in term of knowledge and attitude through mother support group. Journal of Education and Learning (EduLearn). https://doi.org/10.11591/edulearn.v6i 2.148

Huang, P., Ren, J., Liu, Y., Luo, B., \& Zhao, X. (2017). Factors affecting breastfeeding adherence among Chinese mothers: A multicenter study. Medicine (United States). https://doi.org/10.1097/MD.0000000 000007619

Keloglan, S., Yilmaz, A., \& Gumus, K. (2018). Factors Affecting mothers' breastfeeding. In International Journal of Caring Sciences.

Kemenkes. (2015). Infodatin-Asi(1).Pdf. Profil Kesehatan Indonesia. https://doi.org/10.1300/J095v11n02_ 07

Kemenkes RI. (2018). Hasil Utama Riset Kesehatan Dasar Tahun 2018. Kementrian Kesehatan Republik Indonesia. $\quad$ https://doi.org/1 Desember 2013

Knowledge, attitude and intending practice of female undergraduates about breastfeeding. (2014). African Journal of Food, Agriculture, Nutrition and Development.

Maharlouei MD, N., Pourhaghighi Medical student, A., Raeisi Shahraki 
PhD, H., Zohoori MD, D., \& Lankarani MD, K. B. (2018). Factors affecting exclusive breastfeeding, using adaptive LASSO Regression. International Journal of Community Based Nursing and Midwifery.

Maryam, Z., Moniralsadat, H. T., Zohreh, K., Banafsheh, M. Z., \& Amir, S. (2014). The knowledge and attitudes towards breastfeeding of Iranian mothers during the first year after delivery in 2013. Open Access Macedonian Journal of Medical Sciences. https://doi.org/10.3889/oamjms.2014. 114

Mogre, V., Dery, M., \& Gaa, P. K. (2016). Knowledge, attitudes and determinants of exclusive breastfeeding practice among Ghanaian rural lactating mothers. International Breastfeeding Journal. https://doi.org/10.1186/s13006-0160071-z

Nandini, N., Handayani, N., Chalidyanto, D., Pudjirahardjo, W. J., \& Putri, N. K. (2019). Knowledge on breastfeeding and breastfeeding behavior among working mothers and housewives: A Cohort Study. Journal of Public Health for Tropical and Coastal Region.

Notoatmodjo, S. (2012). Promosi kesehatan dan perilaku kesehatan. in Journal of Chemical Information and Modeling. https://doi.org/10.1017/CBO9781107 415324.004

Nukpezah, R. N., Nuvor, S. V., \& Ninnoni, J. (2018). Knowledge and practice of exclusive breastfeeding among mothers in the tamale metropolis of Ghana. Reproductive Health. https://doi.org/10.1186/s1 2978-018-0579-3

Orabi, A., al-Sayad, R., \& Alharthi, K. (2017). Investigating the knowledge, attitudes, practices and perceived barriers of breast feeding among Saudi Women in the National Guard Hospital Jeddah. Athens Journal of
Health.

https://doi.org/10.30958/ajh.4-3-4

Ozenoglu, A., Sokulmez Kaya, P., Asal Ulus, C., \& Alakus, K. (2017). The relationship of knowledge and breastfeeding practice to maternal BMI. Ecology of Food and Nutrition. https://doi.org/10.1080/03670244.20 16.1275604

Peraturan Pemerintah RI No.33 Tahun. (2012). PEMBERIAN AIR SUSU IBU EKSKLUSIF.

Pitaloka, D. A., Abrory, R., \& Pramita, A. D. (2018). Hubungan antara pengetahuan dan pendidikan ibu dengan pemberian ASI Eksklusif di Desa Kedungrejo Kecamatan Waru Kabupaten Sidoarjo. Amerta Nutrition. https://doi.org/10.20473/amnt.v2i3.2 018.265-270

Septiani, H. U., Budi, A., \& Karbito, K. (2017). Faktor-faktor yang berhubungan dengan pemberian ASI Eksklusif oleh ibu menyusui yang bekerja sebagai tenaga kesehatan. Jurnal Aisyah: Jurnal Ilmu Kesehatan. https://doi.org/10.30604/jika.v2i2.62

Srimiyati, S. (2018). Association between husband support with exclusive breastfeeding mother to child age 7-12 months. Jurnal Kesehatan Saelmakers PERDANA. https://doi.org/10.32524/jksp.v1i1.33 6

Susilowati, S. D., Suryawan, I. W. B., \& Widiasa, A. A. M. (2018). Hubungan pengetahuan ibu dengan pencapaian ASI eksklusif anak yang dirawat di Ruang Kaswari RSUD Wangaya Kota Denpasar. Medicina. https://doi.org/10.15562/medicina.v4 9i2.367

WHO. (2015). Breastfeeding policy brief. Breastfeeding Policy Brief. https://doi.org/10.1002/Lawyers

World Health Organisation. (2017). Protecting, promoting and supporting breastfeeding in facilities providing maternity and newborn services. In World Health Organisation. 